\title{
Novel Behavior of Thiiranium Radical Cation Intermediates. Reactions of Dimethyl Disulfide with Alkenes in the Presence of $\operatorname{Pd}(\mathbf{O A c})_{2}$
}

\author{
Hiroshi Takeuchi*, Junnichi Takatori and Shingo Iizuka \\ Department of Chemical Science and Engineering, Faculty of Engineering, Kobe University, \\ Rokkodai-cho, Nada-ku, Kobe 657-8501, Japan \\ Tel.: +81-78-803-6190, Fax: +81-78-803-6205, E-mail: takeuchi@kobe-u.ac.jp, \\ URL: http://www.cx.kobe-u.ac.jp/takeuchi/index.html
}

Received: 8 March 2000; revised form: 7 June 2000 / Accepted: 20 June 2000 / Published: 7 July 2000

\begin{abstract}
Reaction of dimethyl disulfide (1) with cyclohexene (2a) in $\mathrm{AcOH}$ in the presence of $\mathrm{Pd}(\mathrm{OAc})_{2}$ yields trans-1-acetoxy-2-methylcyclohexane (3a). The equivalent reactions with hex-1-ene (2b) and 2-methylpent-1-ene (2c) or 1-methylcyclohex-1-ene (2d) preferentially give anti-Markovnikov and Markovnikov adducts $\mathbf{4}$ and $\mathbf{3}$, respectively, by acetoxymethylthiolation of the alkene. The Markovnikov regioselectivity $\mathbf{3 b} \mathbf{b} \mathbf{4 b}$ for the reaction with $\mathbf{2 b}$ is higher than that for the reaction using $\mathrm{AgOAc}$ instead of $\mathrm{Pd}(\mathrm{OAc})_{2}$, which proceeds via a thiiranium ion. Addition of a polar solvent $\left(\mathrm{MeCN}\right.$ or $\left.\mathrm{MeNO}_{2}\right)$ to the reactions with $\mathbf{2 b}$ or $\mathbf{2 c}$ using $\mathrm{Pd}(\mathrm{OAc})_{2}$ abnormally decreases the Markovnikov regioselectivity. The total yield of $\mathbf{3}$ and $\mathbf{4}$ increases with an increased concentration of $\mathrm{AcOH}$. Compounds $\mathbf{3}$ and 4 are also formed and the reactions in $\mathrm{MeCN}$ or $\mathrm{MeNO}_{2}$ not containing $\mathrm{AcOH}$. A solution of $\mathrm{Pd}(\mathrm{OAc})_{2}$ in 1 exhibits $\lambda_{\max } 380 \mathrm{~nm}(\log \varepsilon$ 3.6) assigned to the absorption of a relatively stable sulfonium salt. These indicate that the reactions using $\mathrm{Pd}(\mathrm{OAc})_{2}$ proceed by $\mathrm{S}_{\mathrm{N}} 2$ ringopening of a new type of thiiranium radical cations paired with ${ }^{-} \mathrm{OAc}$ via the sulfonium salts. The insensitivity of the $3 / 4$ ratios to the reaction time at $25-60^{\circ} \mathrm{C}$ in the reactions with 2c-d shows the ring-opening to be controlled kinetically, but the increased ratio with reaction time at $116^{\circ} \mathrm{C}$ in the reaction with $\mathbf{2 b}$ suggests that the ring-opening is thermodynamically governed. The reaction product with $\mathbf{2 d}$ also undergoes a skeletal rearrangement to a thietanium radical cation to give 1-acetoxymethyl-2-methylthiocyclohexane.
\end{abstract}

Keywords: Dimethyl disulfide, Palladium (II) acetate, Acetoxymethylthiolation, Thiiranium radical cation, Regioselectivity for $\mathrm{S}_{\mathrm{N}} 2$ ring-opening, Solvent effects, Thietanium radical cation, Skeletal rearrangement. 


\section{Introduction}

Thiiranium ion intermediates have been generated by reactions of disulfides with alkenes in the presence of oxidants such as $\mathrm{Pb}(\mathrm{OAc})_{4}$ [1-4], $\mathrm{Mn}(\mathrm{OAc})_{3}$ [2-4], $\mathrm{Fe}(\mathrm{OAc})_{3}$ [2-4] or $\mathrm{Cu}(\mathrm{OAc})_{2}$ [5], by reactions of $\beta$-thiohalides with $\mathrm{AgY}[6]$ and by reactions of thiiranes with $\mathrm{RY}$ [6]. The intermediates which have soft counterions such as $\mathrm{BF}_{4}{ }^{-}, \mathrm{PF}_{6}{ }^{-}, \mathrm{SbF}_{6}{ }^{-}, \mathrm{SbCl}_{5}{ }^{-}, \mathrm{FSO}_{3}{ }^{-}$and $\mathrm{CF}_{3} \mathrm{CO}_{2}{ }^{-}$behave like carbenium ions [1] of a weakly bridged strong electrophile, undergoing a rapid ring-opening by the outer nucleophile at low temperature $\left(-20-0^{\circ} \mathrm{C}\right)$ to give the observed predominant Markovnikov regioselectivity; in some cases, the skeletal rearrangement or stereoconversion of the thiiranium ions has been observed. We may infer that the reactions of $\mathrm{RSCl}$ with alkenes would generate not a $\sigma$-sulfurane but a strongly bridged thiiranium ion pairing tightly with hard $\mathrm{Cl}^{-}[1]$, and thus the ring-opening by the pairing $\mathrm{Cl}^{-}$leads to the anti-Markovnikov regioselectivity without undergoing the stereoconversion and skeletal rearrangement.

In this work, reactions of dimethyl disulfide with 2-alkyl and 2,2-dialkylalkenes in $\mathrm{AcOH}$ in the presence of $\mathrm{Pd}(\mathrm{OAc})_{2}$ lead to the anti-Markovnikov and Markovnikov regioselectivity products, respectively, for the addition to the alkenes. Interestingly, the Markovnikov regioselectivity is lower than that observed for thiiranium ion intermediates, and is decreased by addition of polar solvents such as $\mathrm{MeCN}$ or $\mathrm{MeNO}_{2}$ or the nonpolar solvent $n$-hexane. This novel behavior can be reasonably explained by considering a $S_{N} 2$ ring-opening mechanism of a new type of thiiranium radical cation intermediates paired with ${ }^{-}$OAc. Furthermore, the reaction with 1-methylcyclohex-1-ene yields a product via an anionotropic rearrangement of the thiiranium radical cation intermediate to a thietanium radical cation intermediate.

\section{Results and Discussion}

Reactions with Cyclohexene (2a)

Reaction of dimethyl disulfide (1) with cyclohexene (2a) in $\mathrm{AcOH}$ in the presence of $\mathrm{Pd}(\mathrm{OAc})_{2}$ produced only trans-1-acetoxy-2-methylthiocyclohexane (3a) at 25 or $116^{\circ} \mathrm{C}$ (Table 1). The structure of 3a was assigned to the trans-form on accord of the fact that the mass spectra of $\mathbf{3 a}$ were identical with those of the product formed by the reaction of cyclohexene oxide with $\mathrm{MeSH}$ in benzene (Scheme 1). The trans-configuration shows that $\mathbf{3 a}$ arises from an $\mathrm{S}_{\mathrm{N}} 2$ ring-opening of a three-membered ring intermediate, and that the intermediate is still stable at $116^{\circ} \mathrm{C}$ without transforming to the corresponding carbocation at such a high temperature.

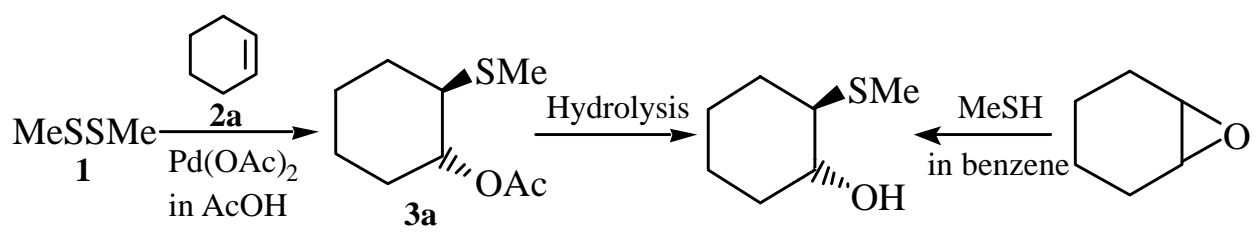

Scheme 1. 
Table 1. Reactions in the presence of $\mathrm{Pd}(\mathrm{OAc})_{2}(0.68 \mathrm{mmol})$ of dimethyl disulfide (1) $(2.0 \mathrm{mmol})$ with $4.8 \mathrm{mmol}$ of cyclohexene $(\mathbf{2 a})$ and hex-1-ene $(\mathbf{2 b})$ in $\mathrm{AcOH}\left(10.0 \mathrm{~cm}^{3}\right)$ containing $\mathrm{Ac}_{2} \mathrm{O}\left(1.0 \mathrm{~cm}^{3}\right)$.

\begin{tabular}{|c|c|c|c|c|c|}
\hline Alkene & $\mathbf{T} /{ }^{\mathbf{0}} \mathbf{C}$ & $\mathbf{t} / \mathbf{h}$ & \multicolumn{2}{|c|}{ Yield $^{\boldsymbol{a}}(\mathbf{\%})$} & Ratio \\
\hline & & & $\mathbf{3}$ & $\mathbf{4}$ & $\mathbf{3 / 4}$ \\
\hline $\mathbf{2 a}$ & 25 & 24 & $69^{b}$ & - & - \\
\hline $\mathbf{2 a}$ & 116 & 24 & $68^{b}$ & - & - \\
\hline $\mathbf{2 b}$ & 0 & 2.0 & 5.6 & 15 & 0.37 \\
\hline $\mathbf{2 b}$ & 0 & 4.0 & 8.8 & 24 & 0.37 \\
\hline $\mathbf{2 b}$ & 25 & 2.0 & 14 & 32 & 0.44 \\
\hline $\mathbf{2 b}$ & 25 & 24 & 16 & 37 & 0.43 \\
\hline $\mathbf{2 b}$ & 25 & 96 & 16 & 36 & 0.44 \\
\hline $\mathbf{2 b}$ & 60 & 1.0 & 13 & 29 & 0.45 \\
\hline $\mathbf{2 b}$ & 60 & 2.0 & 20 & 40 & 0.50 \\
\hline $\mathbf{2 b}$ & 116 & 1.0 & 17 & 23 & 0.74 \\
\hline $\mathbf{2 b}$ & 116 & 2.0 & 36 & 34 & 1.1 \\
\hline $\mathbf{2 b}$ & 116 & 24 & 76 & 17 & 4.5 \\
\hline
\end{tabular}

${ }^{a}$ The yields are calculated to be $100 \%$ when two moles of product is formed from one mole of $\mathrm{Pd}(\mathrm{OAc})_{2}$ used, and were obtained by GLC analysis; ${ }^{1} \mathrm{H}$ NMR analysis gave nearly the same results. ${ }^{b}$ The trans-stereochemistry is assigned by the fact that the compound given by hydrolysis of 3a is identical with that formed by $\mathrm{S}_{\mathrm{N}} 2$ reaction of cyclohexene oxide with $\mathrm{MeSH}$ in benzene.

\section{Reactions with Hex-1-ene (2b)}

The reaction with hex-1-ene $(\mathbf{2 b})$ at $0-60^{\circ} \mathrm{C}$ gave preferentially the anti-Markovnikov adduct $\mathbf{4 b}$, and the $\mathbf{3 b} / \mathbf{4 b}$ ratio was observed to increase with temperature (Table 1 ). The ratio at $0-60^{\circ} \mathrm{C}$ was almost insensitive to the reaction time whereas the ratio at $116^{\circ} \mathrm{C}$ was enhanced in the prolonged reaction (Table 1). The insensitivity of the ratio to the reaction time means that the reaction is controlled kinetically at $0-60^{\circ} \mathrm{C}$, but thermodynamically governed at $116^{\circ} \mathrm{C}$. In fact, when a mixture of $\mathbf{3 b} / \mathbf{4 b}=0.34$ was treated in $\mathrm{AcOH}$, the ratio $3 \mathbf{b} / \mathbf{4 b}$ at $25^{\circ} \mathrm{C}$ did not change for $24 \mathrm{~h}$, but the ratio at $116^{\circ} \mathrm{C}$ increased to 1.4 or 6.6 after $2 \mathrm{~h}$ or $24 \mathrm{~h}$, respectively. The preferential formation of anti-Markovnikov adduct at $0-60^{\circ} \mathrm{C}$ suggests that the kinetic $\mathrm{S}_{\mathrm{N}} 2$ ring-opening of the final three-membered ring intermediate is principally affected by steric factors (Scheme 2 ).

\section{Formation of Thiiranium Radical Cations II and II' from Sulfonium Salts I and I'}

From the above trans-addition, the final intermediate for the formation of the products should be logically three membered ring intermediates. As an oxidant $\mathrm{Pd}(\mathrm{OAc})_{2}$ can act in two ways. The first action is electron transfer: One electron transfer from 1 to $\mathrm{Pd}(\mathrm{OAc})_{2}$ forms a disulfide radical cation [7], and the radical cation and/or a sulfenium ion [8] arising from the radical cation should generate a thiiranium ion as the final intermediate by attack on the alkene. As seen in Tables 1 and 4, the reaction using $\mathrm{Pd}(\mathrm{OAc})_{2}$ shows higher Markovnikov regioselectivity $(\mathbf{3 b} / \mathbf{4 b}=0.44)$ at $25^{\circ} \mathrm{C}$ than that observed at $25^{\circ} \mathrm{C}(0.27)$ in the reaction via a thiiranium ion [9] using $\mathrm{AgOAc}$ instead of $\mathrm{Pd}(\mathrm{OAc})_{2}$. Furthermore, 
the Markovnikov regioselectivity $\mathbf{3 / 4}$ for the reaction using $\mathrm{Pd}(\mathrm{OAc})_{2}$ is unusually decreased on dilution with a polar solvent $\left(\mathrm{MeCN}\right.$ or $\left.\mathrm{MeNO}_{2}\right)$ while that using $\mathrm{AgOAc}$ is increased on dilution with $\mathrm{MeNO}_{2}$ (Table 3). These data show that the reaction using $\mathrm{Pd}(\mathrm{OAc})_{2}$ does not proceed via a thiiranium ion, and thus this action for $\mathrm{Pd}(\mathrm{OAc})_{2}$ can be ruled out. Another action is coordination. $\mathrm{Pd}(\mathrm{OAc})_{2}$ coordinates to $\mathbf{1}$ to give sulfonium ions I and I' (Scheme 2). The sulfonium ions undergo a homolytic $S-S$ scission by spontaneous or induced (by $\mathrm{AcOH}$ ) decomposition to give MeS• and thiiranium radical cations II and II' which bond with the Pd atom (Scheme 2). If a heterolytic $S$ - $S$ scission of I and I' occurs, then thiiranium ion intermediates should be formed by reaction with sufenium fragment. Thus, the heterolytic scission can be excluded. Therefore, the latter action predominates and II and II' as the final intermediates should be formed by the homolytic $S$-S scission of I and I' (Scheme 2). The following evidence supports the fact that the products are formed via thiiranium radical cations II and II' from sulfonium ions I and I'.

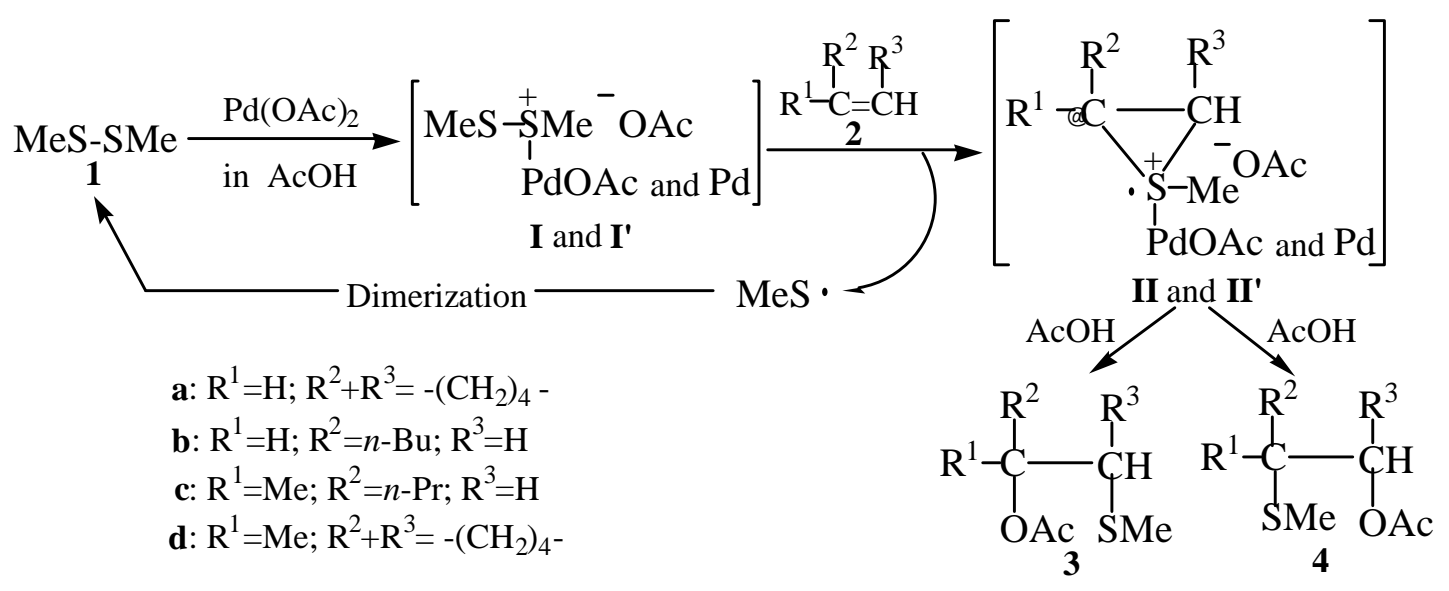

Scheme 2.

A solution containing $\mathrm{Pd}(\mathrm{OAc})_{2}$ in $\mathrm{AcOH}$ also containing $\mathrm{Ac}_{2} \mathrm{O}(9.1 \% \mathrm{v} / \mathrm{v})$ shows $\lambda_{\max } 397 \mathrm{~nm}(\log$ $\varepsilon$ 2.3) at $25^{\circ} \mathrm{C}$ while a solution made by dissolving $\mathrm{Pd}(\mathrm{OAc})_{2}$ in $\mathbf{1}$ at $25^{\circ} \mathrm{C}$ has $\lambda_{\max } 380 \mathrm{~nm}(\log \varepsilon$ 3.6). The species with $\lambda_{\max } 380 \mathrm{~nm}$ shows the half life-time $c a .30 \mathrm{~h}$ in $\mathbf{1}$, so that the species could not be the unstable disulfide radical cation [7] but rather a sulfonium salt I [MeS-S ${ }^{+}(\mathrm{Me}) \mathrm{PdOAc}{ }^{-} \mathrm{OAc}$. When different oxidants $\mathrm{AgOAc}$ and $\mathrm{AlCl}_{3}$ are dissolved in 1, we can observe the same $\lambda_{\max } 375 \mathrm{~nm}$ with a very short lifetime. Thus, the species with $\lambda_{\max } 375 \mathrm{~nm}$ might be the disulfide radical cation, which would be independent of oxidative metals [7]. Considering that the intermediate using $\mathrm{AlCl}_{3}$ can bring about an aromatic methylthiolation [7] whereas that using AgOAc is not subject to the aromatic methylthiolation but can react with alkene to form a thiiranium ion [9], we can regard the following: a very small amount of the disulfide radical cation and a more large amount of a sulfonium ion [MeS$\left.\mathrm{S}^{+}(\mathrm{Me}) \mathrm{Ag}\right]^{-} \mathrm{OAc}$ (this has no visible absorption due to a $\sigma \mathrm{S}-\mathrm{Ag}$ bond) are generated as the intermediates when $\mathrm{AgOAc}$ is dissolved in $\mathbf{1}$. Dissolving $\mathrm{AlCl}_{3}$ in $\mathbf{1}$, the disulfide radical cation is only formed as the intermediate.

During the reaction of $\mathbf{1}$ with $\mathbf{2 b}$ using $\mathrm{Pd}(\mathrm{OAc})_{2}$, we obtained a small amount of a dark reddish powdery precipitate having $v_{\max }(\mathrm{KBr}) / \mathrm{cm}^{-1} 2900$ and $2980(\mathrm{C}-\mathrm{H}), 1577$ and $1410\left(-\mathrm{CO}_{2}^{-}\right), 1050$, 1020, 950, 930 and $652(\mathrm{C}-\mathrm{S})$. This precipitate might be a sulfonium salt $\mathbf{I}^{\prime}\left[\mathrm{MeS}^{-\mathrm{S}^{+}}(\mathrm{Me}) \mathrm{Pd}\right]^{-} \mathrm{OAc}$; this salt does not have ${ }^{-} \mathrm{OAc}$ attached to $\mathrm{Pd}$ since the carbonyl of $\mathrm{Pd}(\mathrm{OAc})_{2}$ appears at $c a .1610 \mathrm{~cm}^{-1}$. 
Considering that one mole of product is formed from one mole of $\operatorname{Pd}(\mathrm{OAc})_{2}$, then we observe that the total yield of $\mathbf{3}$ and $\mathbf{4}$ is more than 100\%. Thus, the generation of the two species $\mathbf{I}$ and $\mathbf{I}$ ' from one mole of $\mathrm{Pd}(\mathrm{OAc})_{2}$ is reasonable.

The novel behavior for the reaction using $\mathrm{Pd}(\mathrm{OAc})_{2}$ instead of $\mathrm{AgOAc}$ (i.e. the high $\mathbf{3 b} \mathbf{\mathbf { 4 }} \mathbf{b}$ ratio using $\mathrm{Pd}(\mathrm{OAc})_{2}$ relative to $\mathrm{AgOAc}$ and the decreased $\mathbf{3 b} / \mathbf{4 b}$ ratio upon addition of polar solvent) as described above is probably due to the higher positive charge on the $C_{2}$-carbon of II than that of the corresponding thiiranium ion since II contains a positive Pd atom; the effect of polar solvent is explained below. The possibility that the final intermediate is a thiiranium dication formed by attack of thiiranium ion on $\mathrm{Pd}(\mathrm{OAc})_{2}$ can be excluded on account of charge-repulsion between the positive species on the attack.

\section{Reactions with 2-Methylpent-1-ene (2c)}

The reaction with 2-methylpent-1-ene $\mathbf{2 c}$ gave the Markovnikov regioselectivity exhibiting $\mathbf{3 c} / \mathbf{4 c}$ of ca. 1.8 at $0-60^{\circ} \mathrm{C}$, and the ratio was almost insensitive to reaction time (Table 2). The time-insensitivity reflects the product stability, and means that the ring-opening of the intermediates IIc and II'c is controlled kinetically. The Markovnikov regioselectivity indicates that the ring-opening of IIc and II'c is mostly governed electronically. The reaction with $2 \mathrm{c}$ at $116^{\circ} \mathrm{C}$ is described below.

Table 2. Reactions of dimethyl disulfide 1 (2.0 mmol) with 2-methylpent-1-ene $\mathbf{2 c}$ and 1-methylcylohex-1-ene $2 \mathbf{d}$ of $4.8 \mathrm{mmol}$ in the presence of $\mathrm{Pd}(\mathrm{OAc})_{2}(0.68 \mathrm{mmol})$ in $\mathrm{AcOH}\left(10 \mathrm{~cm}^{3}\right)$ containing $\mathrm{Ac}_{2} \mathrm{O}\left(1.0 \mathrm{~cm}^{3}\right)$.

\begin{tabular}{|c|c|c|c|c|c|c|}
\hline Alkene & $\mathbf{T} / \mathbf{~}^{\mathbf{C}}$ & $\mathbf{t} / \mathbf{h}$ & \multicolumn{3}{|c|}{ Yield $^{\boldsymbol{a}} \mathbf{( \% )}$} & Ratio \\
\hline & & & $\mathbf{3}$ & $\mathbf{4}$ & $\mathbf{5}$ & $\mathbf{3 / 4}$ \\
\hline $\mathbf{2 c}$ & 0 & 2.0 & 15 & 8.5 & 0 & 1.8 \\
\hline $\mathbf{2 c}$ & 0 & 4.0 & 20 & 11 & 0 & 1.8 \\
\hline $\mathbf{2 c}$ & 25 & 2.0 & 18 & 10 & 0 & 1.8 \\
\hline $\mathbf{2 c}$ & 25 & 24 & 34 & 17 & 0 & 2.0 \\
\hline $\mathbf{2 c}$ & 60 & 2.0 & 24 & 13 & 0 & 1.8 \\
\hline $\mathbf{2 c}$ & 60 & 4.0 & 47 & 26 & 0 & 1.8 \\
\hline $\mathbf{2 d}$ & 0 & 2.0 & 15 & 4.1 & 3.2 & 3.7 \\
\hline $\mathbf{2 d}$ & 0 & 4.0 & 26 & 7.4 & 2.8 & 3.5 \\
\hline $\mathbf{2 d}$ & 25 & 2.0 & 30 & 10 & 5.3 & 3.0 \\
\hline $\mathbf{2 d}$ & 25 & 24 & 39 & 14 & 3.5 & 2.8 \\
\hline 2d & 60 & 2.0 & 38 & 14 & 3.5 & 2.7 \\
\hline 2d & 60 & 4.0 & 44 & 20 & 4.1 & 2.2 \\
\hline
\end{tabular}

${ }^{a}$ The yields are calculated as shown in Table 1. The products $3 \mathbf{d}$ or $\mathbf{4 d}$ correspond to trans-1acetoxy-1- or -2-methyl-2-methylthiocyclohexane, respectively. 
The reaction with 1-methylcyclohex-1-ene $(\mathbf{2 d})$ at $25-60^{\circ} \mathrm{C}$ gives predominantly Markovnikov transadduct ( $\mathbf{3 d} / \mathbf{4 d}=3.7-2.2$ ) (Table 2). This can be also interpreted by the idea that the $\mathrm{S}_{\mathrm{N}} 2$ ring-opening of IId and II'd occurs under preferential electronic control. A slightly lower ratio in the prolonged reaction (Table 2) is presumably due to the thermodynamic instability of $\mathbf{3 d}$ compared to $\mathbf{4 d}$.

We obtained 1-acetoxymethyl-2-methylthiocyclohexane (5d) in the reaction with $\mathbf{2 d}$, but did not obtain the corresponding $\mathbf{5 c}$ in the reaction with $\mathbf{2 c}$ (Table 2). According to the molecular model, the $S$-atom of IId and II'd is closer to the 2-methyl carbon than that of IIc and II'c, so IId and II'd may rearrange to the thietanium radical cations IIId and III'd by a concerted reaction involving $C_{2}-S$ bond breaking and hydride migration of the 2-methyl group, leading to $\mathbf{5 d}$ (Scheme 3). A similar anionotropic rearrangement from thiiranium ion to thietanium ion has been proposed for the concerted reaction involving $C_{2}-S$ breaking and methyl migration at tertiary carbon [10-14].

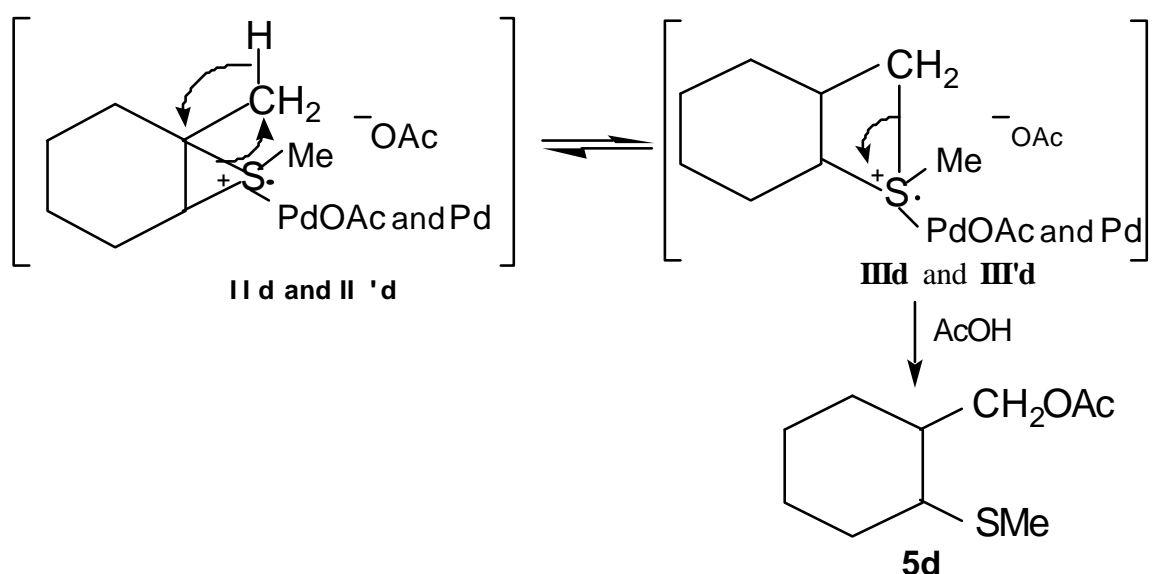

Scheme 3.

The reaction with $\mathbf{2 c}$ or $\mathbf{2} \mathbf{d}$ at $116^{\circ} \mathrm{C}$ gave many unidentified products according to GLC analysis. A stable tertiary carbocation is probably formed by bridge-cleavage of IIc and II'c or IId and II'd at a high temperature such as $116^{\circ} \mathrm{C}$, hence this result. But IIa and II'a or IIb and II'b, which cannot generate a tertiary carbocation by the cleavage are still bridged at $116^{\circ} \mathrm{C}$, thus yielding $\mathbf{3 a}$ or $\mathbf{3 b}$ and $\mathbf{4 b}$ by the $\mathrm{S}_{\mathrm{N}} 2$ ring-opening.

\section{Effects of Solvent and Concentration of $\mathrm{AcOH}$}

The total yield of $\mathbf{3}$ and $\mathbf{4}$ in the reaction with $\mathbf{2 b}$ or $\mathbf{2 c}$ in $\mathrm{AcOH}-\mathrm{CH}_{2} \mathrm{Cl}_{2}$ increases with an increase in the concentration of $\mathrm{AcOH}$, and $\mathbf{3 b}$ and $\mathbf{4 b}$ are also produced in the reaction in $\mathrm{MeCN}$ or $\mathrm{MeNO}_{2}$ not containing $\mathrm{AcOH}$ (Table 3). These indicate that $\mathbf{3}$ and $\mathbf{4}$ are formed by the $\mathrm{S}_{\mathrm{N}} 2$ attack on II and II' of both AcOH and $\mathrm{AcO}^{-}$pairing with II and II' (Scheme 2).

In the reaction with $\mathbf{2 b}$ or $\mathbf{2 c}$, the Markovnikov regioselectivity $\mathbf{3 / 4}$ was interestingly decreased upon dilution with $\mathrm{CH}_{2} \mathrm{Cl}_{2}$ or the polar solvents $\mathrm{MeCN}$ or $\mathrm{MeNO}_{2}$, and it was also depressed on dilution with nonpolar $n$-hexane (Table 3). By contrast, in the reaction of $\mathbf{1}$ with $\mathbf{2 b}$ using $\mathrm{AgOAc}$ instead of $\mathrm{Pd}(\mathrm{OAc})_{2}$, the Markovnikov regioselectivity for the ring-opening of thiiranium ion was increased on dilution with $\mathrm{MeNO}_{2}($ Table 3). 
Table 3. Effects of solvents on the reaction of dimethyl disulfide (1) (2.0 mmol) with hex-1-ene (2b) $(4.8 \mathrm{mmol})$ or 2-methylpent-1-ene $(2 \mathrm{c})(4.8 \mathrm{mmol})$ in the presence of $\mathrm{Pd}(\mathrm{OAc})_{2}(0.68 \mathrm{mmol})$ at $25^{\circ} \mathrm{C}$ for $24 \mathrm{~h}$.

\begin{tabular}{|c|c|c|c|c|c|c|c|c|}
\hline \multirow[t]{2}{*}{ Alkene } & \multicolumn{5}{|c|}{ Solvent $\left(\mathrm{cm}^{3}\right)$} & \multicolumn{2}{|c|}{ Yield $^{a}(\%)$} & \multirow{2}{*}{\begin{tabular}{|c|} 
Ratio \\
$3 / 4$ \\
\end{tabular}} \\
\hline & AcOH & $\mathrm{CH}_{2} \mathrm{Cl}_{2}$ & $n-\mathrm{C}_{6} \mathrm{H}_{14}$ & $\mathrm{MeCN}$ & $\mathrm{MeNO}_{2}$ & 3 & 4 & \\
\hline $2 b$ & 10 & 0 & 0 & 0 & 0 & 16 & 37 & 0.43 \\
\hline $2 \mathbf{b}$ & 9.0 & 1.0 & 0 & 0 & 0 & 12 & 29 & 0.41 \\
\hline $2 \mathrm{~b}$ & 5.0 & 5.0 & 0 & 0 & 0 & 10 & 26 & 0.38 \\
\hline $2 \mathrm{~b}$ & 1.0 & 9.0 & 0 & 0 & 0 & 6.5 & 19 & 0.34 \\
\hline $2 b$ & 5.0 & 0 & 5.0 & 0 & 0 & 5.3 & 14 & 0.38 \\
\hline $2 b$ & 0 & 0 & 0 & 10 & 0 & 4.1 & 17 & 0.24 \\
\hline $2 b$ & 0 & 0 & 0 & 0 & 10 & 3.2 & 17 & 0.19 \\
\hline $2 b$ & 5.0 & 0 & 0 & 0 & 5.0 & 13 & 42 & 0.31 \\
\hline $2 \mathbf{b}^{b}$ & 10 & 0 & 0 & 0 & 0 & 5.2 & 19 & 0.27 \\
\hline $2 \mathbf{b}^{b}$ & 5.0 & 0 & 0 & 0 & 5.0 & 5.4 & 16 & 0.34 \\
\hline $2 c$ & 10 & 0 & 0 & 0 & 0 & 34 & 17 & 2.0 \\
\hline $2 c$ & 9.0 & 1.0 & 0 & 0 & 0 & 31 & 18 & 1.7 \\
\hline $2 c$ & 5.0 & 5.0 & 0 & 0 & 0 & 24 & 18 & 1.3 \\
\hline $2 c$ & 1.0 & 9.0 & 0 & 0 & 0 & 16 & 19 & 0.84 \\
\hline $2 c$ & 9.0 & 0 & 1.0 & 0 & 0 & 32 & 20 & 1.6 \\
\hline $2 c$ & 5.0 & 0 & 5.0 & 0 & 0 & 15 & 12 & 1.3 \\
\hline $2 \mathrm{c}$ & 1.0 & 0 & 9.0 & 0 & 0 & 17 & 13 & 1.3 \\
\hline $2 c$ & 5.0 & 0 & 0 & 0 & 5.0 & 47 & 27 & 1.7 \\
\hline
\end{tabular}

${ }^{a}$ The yields are calculated to be $100 \%$ when two moles of product is formed from one mole of $\mathrm{Pd}(\mathrm{OAc})_{2}$ and from two moles of $\mathrm{AgOAc}$, and were obtained by GLC analysis; $\mathrm{Ac}_{2} \mathrm{O}\left(1.0 \mathrm{~cm}^{3}\right)$ is added to these reactions, but $\mathrm{Ac}_{2} \mathrm{O}$ is not used in the reactions with only $\mathrm{MeCN}$ or $\mathrm{MeNO}_{2}$.

${ }^{b} \mathrm{AgOAc}(1.36 \mathrm{mmol})$ instead of $\mathrm{Pd}(\mathrm{OAc})_{2}$ was used in this reaction.

The decreased Markovnikov regioselectivity observed on dilution with the polar solvents suggests that the solvation with the polar solvent occurs strongly at the highly charged C-2 of II and II' rather than at the low charged C-3, suppressing the $\mathrm{S}_{\mathrm{N}} 2$ reactivity at C-2 relative to the C-3. The depressed $\mathbf{3 b} \mathbf{4} \mathbf{b}$ ratio upon dilution with nonpolar $n$-hexane allows us to infer that this dilution transforms the solvent separated ion-pair of II and II' into a tight ion-pair in which the counteranion interacts to a greater extent with the more positive C-2 of II and II' than the less positive C-3 to decrease the $\mathrm{S}_{\mathrm{N}} 2$ reactivity more at the $\mathrm{C}-2$ than the $\mathrm{C}-3$, leading to the observed results.

\section{Effects of Oxidants}

As described above, the oxidative attack of $\mathrm{Pd}(\mathrm{OAc})_{2}$ on $\mathbf{1}$ may form the sulfonium salts $\mathbf{I}$ and $\mathbf{I}$ ', giving thiiranium radical cations II and II' and MeS• (Scheme 2); MeS• dimerizes to give $\mathbf{1}$ because 
of an unfavorable reaction with 2 [15]. An addition of $\mathrm{Cu}(\mathrm{OAc})_{2}$ to the reaction with $\mathbf{2 b}$ using $\mathrm{Pd}(\mathrm{OAc})_{2}$ resulted in rather suppressed yields of $\mathbf{3 b}$ and $\mathbf{4 b}$ (Tables 1 and 4). The use of $\mathrm{Cu}(\mathrm{OAc})_{2}$, $\mathrm{Mn}(\mathrm{OAc})_{3}$ or $\mathrm{Pb}(\mathrm{OAc})_{4}$ instead of $\mathrm{Pd}(\mathrm{OAc})_{2}$ in the reaction with $\mathbf{2} \mathbf{b}$ did not yield the products $\mathbf{3 b}$ and 4b (Table 4); $\mathrm{Cu}(\mathrm{OAc})_{2}$ forms a complex with the alkene, and thus it would not operate as oxidizing agent. $\mathrm{Mn}(\mathrm{OAc})_{3}$ is not effective since it oxidizes $\mathrm{AcOH}[16] . \mathrm{Pb}(\mathrm{OAc})_{4}$ is too strong an oxidant to be effective, giving a lot of unidentified products. $\mathrm{PdSO}_{4}$ is difficult to dissolve in $\mathrm{AcOH}$, so that it could scarcely be effective. The use of $\mathrm{H}_{2} \mathrm{SO}_{4}$ gave many unidentified products due to the strong acidity, leading to only a trace of the target products. Since AgOAc is complexed with alkene, it would be not so effective for the reaction.

Table 4. Effects of oxidants in the reactions of dimethyl disulfide (1) (2.0 mmol) with hex-1-ene (2b) $(4.8 \mathrm{mmol})$ in the presence of oxidant in $\mathrm{AcOH}\left(10 \mathrm{~cm}^{3}\right)$ containing $\mathrm{Ac}_{2} \mathrm{O}\left(1.0 \mathrm{~cm}^{3}\right)$ at $25^{\circ} \mathrm{C}$ for $24 \mathrm{~h}$.

\begin{tabular}{|l|c|c|c|c|}
\hline \multicolumn{1}{|c|}{ Oxidant } & Oxidant/mmol & \multicolumn{2}{c|}{ Yield $^{\boldsymbol{a}}(\boldsymbol{\%})$} & Ratio \\
\hline & & $\mathbf{3 b}$ & $\mathbf{4 b}$ & $\mathbf{3 b} / \mathbf{4 b}$ \\
\hline $\mathrm{Pd}(\mathrm{OAc})_{2}+\mathrm{Cu}(\mathrm{OAc})_{2}$ & $b$ & 7.7 & 17 & 0.45 \\
\hline $\mathrm{Cu}(\mathrm{OAc})_{2}$ & 0.68 & 0 & 0 & - \\
\hline $\mathrm{H}_{2} \mathrm{SO}_{4}$ & 0.68 & trace & trace & - \\
\hline $\mathrm{PdSO}_{4}$ & 0.68 & trace & trace & - \\
\hline $\mathrm{AgOAc}$ & 1.36 & 5.2 & 19 & 0.27 \\
\hline $\mathrm{Mn}(\mathrm{OAc})_{3}$ & 2.4 & 0 & 0 & - \\
\hline $\mathrm{Pb}(\mathrm{OAc})_{4}$ & 2.4 & 0 & 0 & - \\
\hline
\end{tabular}

${ }^{a}$ The yields are calculated to be $100 \%$ when two moles of product are formed from one mole $\mathrm{Pd}(\mathrm{OAc})_{2}$ or $\mathrm{Cu}(\mathrm{OAc})_{2}$ and from two moles $\mathrm{AgOAc}$.

${ }^{b} \mathrm{Pd}(\mathrm{OAc})_{2}(0.60 \mathrm{mmol})$ and $\mathrm{Cu}(\mathrm{OAc})_{2}(3.6 \mathrm{mmol})$ were used, and the yields are obtained on the basis of $\mathrm{Pd}(\mathrm{OAc})_{2}$.

\section{Experimental}

\section{General}

IR spectra were obtained on a JASCO Cooperation A-302 spectrometer. ${ }^{1} \mathrm{H}$ NMR spectra were taken with a Nippondenshi PMX-60SI instrument ( $J$ values are given in Hz). GLC-MS were recorded with a Shimadzu QP-5000 spectrometer linked to a Shimadzu GC-17A; the column $(15 \mathrm{~m} \times 0.25 \mathrm{~mm}$, coated with a $0.25 \mu \mathrm{m}$ film of DB-1) is made by $\mathrm{J} \& \mathrm{~W}$ Scientific. GLC was performed with a Shimadzu GC-8A using a glass column $(1 \mathrm{~m} \times 3 \mathrm{~mm})$ packed with $10 \%$ SE-30 on 60-80 mesh Chromosorb W (AW-DMCS). Two runs agreed within $3 \%$ error for the yields of the products, which were determined by replicate GLC analyses. The isolation or separation (as a mixture) of the products was done by thin layer chromatography (using Merck Silicagel 60PF254). $\mathrm{AcOH}, \mathrm{CH}_{2} \mathrm{Cl}_{2}, \mathrm{MeCN}, \mathrm{MeNO}_{2}, n$-hexane and ethyl acetate were purified by standard methods before use. The following compounds were reagent grade (Nacalai Tesque), and used without further purification: $\mathrm{Ac}_{2} \mathrm{O}, \mathrm{H}_{2} \mathrm{SO}_{4}, \mathrm{Pd}(\mathrm{OAc})_{2}$, $\mathrm{Cu}(\mathrm{OAc})_{2}, \mathrm{PdSO}_{4}, \mathrm{AgOAc}, \mathrm{Mn}(\mathrm{OAc})_{3}, \mathrm{~Pb}(\mathrm{OAc})_{4}$, dimethyl disulfide (1), cyclohexene (2a), hex-1-ene (2b), 2-methylpent-1-ene (2c) and 1-methyl-cyclohex-1-ene (2d). 


\section{Experimental procedures}

Reactions of dimethyl disulfide (1) with cyclohexene (2a), hex-1-ene (2b), 2-methylpent-1-ene (2c) and 1-methylcyclohex-1-ene (2d) in $\mathrm{AcOH}$ containing $\mathrm{Ac}_{2} \mathrm{O}$ in the presence of $\mathrm{Pd}(\mathrm{OAc})_{2}$

A mixture of $\mathbf{1}$ and alkene (2a, 2b, 2c or $\mathbf{2 d}$ ) was added to a mixture of $\mathrm{AcOH}$ and $\mathrm{Ac}_{2} \mathrm{O}$ in the presence of $\mathrm{Pd}(\mathrm{OAc})_{2}$ with stirring (using a magnetic stirrer) under the conditions described in Tables 1 and 2. After the reaction, any precipitate formed was filtered off, and aqueous $\mathrm{Na}_{2} \mathrm{CO}_{3}$ was added to the filtrate until the solution reached $\mathrm{pH}>7$. The organic layer was extracted with ethyl acetate. The yields of products 3a-d, $\mathbf{4 b - d}$ and $\mathbf{5 d}$ were determined by GLC analysis, and the results are summarized in Tables 1 and 2. Product 3a was isolated by thin layer chromatography, and the structure was confirmed as follows.

\section{Trans-1-acetoxy-2-methylthiocyclohexane (3a)}

Liquid, $v_{\max }\left(\right.$ neat) $/ \mathrm{cm}^{-1} 2930,2860,1734,1450,1375,1235$ and 1048; $\delta_{\mathrm{H}}\left(\mathrm{CDCl}_{3}\right) 1.08-1.09(8 \mathrm{H}$, $\left.\mathrm{m}, \mathrm{CH}_{2}\right), 2.06(3 \mathrm{H}, \mathrm{s}, \mathrm{Me}), 2.09(3 \mathrm{H}, \mathrm{s}, \mathrm{Me}), 2.33-2.80(1 \mathrm{H}, \mathrm{m}, \mathrm{SCH})$ and 4.85-5.08 $(1 \mathrm{H}, \mathrm{m}, \mathrm{OCH})$; GLC-MS, $m / z, 188\left(\mathrm{M}^{+}\right), 128,113,81,80,79,77,61$ and 53. The GC-MS mass spectra for the compound which is formed by hydrolysis of $\mathbf{3 a}$ in aq. $\mathrm{NaOH}$ were identical with those for the product [i.e. trans-1-hydroxy-2-methylthiocyclohexane; $m / z 146\left(\mathrm{M}^{+}\right), 98,87,81,80,79,70,61,57$, and 55] given by a reaction of cyclohexene oxide with $\mathrm{MeSH}$ in benzene. This indicates that product $\mathbf{3 a}$ has a transconfiguration.

The products $\mathbf{3 b}$ and $\mathbf{4 b}$ were not isolated but rather obtained as a mixture by thin layer chromatography. This mixture showed the following spectral data: $v_{\max }$ (neat) $/ \mathrm{cm}^{-1} 2930,2870,1744,1460$, 1380, 1240, 1040 and 818; $\delta_{\mathrm{H}}\left(\mathrm{CDCl}_{3}\right)$ 0.85-1.88 $\left(9 \mathrm{H}, \mathrm{m}, \mathrm{MeCH}_{2} \mathrm{CH}_{2} \mathrm{CH}_{2}\right), 2.08(3 \mathrm{H}, \mathrm{s}, \mathrm{SMe}$ or OCOMe), 2.12 (3H, s, OCOMe or SMe), 2.48-2.78 (br, $\mathrm{SCH}_{2}$ of $\mathbf{3 b}$ ), 2.78-2.3.08 (br, $\mathrm{SCH}$ of $\mathbf{4 b}$ ), 4.18 $\left(\mathrm{ABq}, J=6 \mathrm{~Hz}, \mathrm{OCH}_{2}\right.$ of $\left.\mathbf{4 b}\right)$ and 4.88-5.23 (m, OCH of $\mathbf{3 b}$ ). The products $\mathbf{3 b}$ and $\mathbf{4 b}$ have the following mass spectra by GLC-MS: $\mathrm{m} / \mathrm{z}$ for $\mathbf{3 b} 130\left(\mathrm{M}^{+}-\mathrm{AcOH}\right), 115\left[\mathrm{M}^{+}-(\mathrm{AcOH}+\mathrm{Me})\right], 87(n-$ $\left.\mathrm{BuCH}^{+} \mathrm{OH}\right)$ ), 82 (radical cation of $\left.n-\mathrm{BuC} \equiv \mathrm{CH}\right), 67,61\left(\mathrm{MeSCH}_{2}{ }^{+}\right)$and $55\left(\mathrm{C}_{4} \mathrm{H}_{7}^{+}\right) ; \mathrm{m} / z$ for $4 \mathbf{b} 130$, $115,88,87,82,67,61$ and 55 . The fact that the relative intensity of $\mathrm{m} / z, 130$ and 87 to $\mathrm{m} / z, 55$ is higher in $\mathbf{3 b}$ than in $\mathbf{4 b}$ also suggests these structures. The observation that the GLC peak for $\mathbf{3 b}$ has a shorter retention time than that for $\mathbf{4 b}$ supports the fact that the $\mathrm{AcO}$ group for $\mathbf{3 b}$ is more shielded by non polar groups than the $\mathrm{AcO}$ group for $\mathbf{4 b}$. The yields of $\mathbf{3 b}$ and $\mathbf{4 b}$ were obtained using the assumption that these compounds have the same GLC response factors. A mixture $(33 \mathrm{mg}$ ) containing $\mathbf{3 b}$ and $\mathbf{4 b}$ $(\mathbf{3 b} / \mathbf{4 b}=0.34)$ was treated in $\mathrm{AcOH}\left(10 \mathrm{~cm}^{3}\right)$ containing $\mathrm{Ac}_{2} \mathrm{O}\left(1.0 \mathrm{~cm}^{3}\right)$ at $25^{\circ} \mathrm{C}$ for $24 \mathrm{~h}$ and at $116^{\circ} \mathrm{C}$ for $2 \mathrm{~h}$ or $24 \mathrm{~h}$. Product $3 \mathrm{c}$ was isolated by thin layer chromatography, and the structure was confirmed by the following spectra.

\section{2-Acetoxy-2-methyl-1-methylthiopentane (3c)}

Liquid, $v_{\max }$ (neat) $/ \mathrm{cm}^{-1} 2920,2870,1732,1435,1370,1240,1198,1140,1030$ and 950; $\delta_{\mathrm{H}}$ $\left(\mathrm{CDCl}_{3}\right)$ 0.77-1.88 (7H, m, $\left.\mathrm{MeCH}_{2} \mathrm{CH}_{2}\right), 1.47(3 \mathrm{H}, \mathrm{s}, \mathrm{Me}), 1.96(3 \mathrm{H}, \mathrm{s}, \mathrm{OCOMe}), 2.11(3 \mathrm{H}, \mathrm{s}, \mathrm{SMe})$ and $2.98\left(2 \mathrm{H}, \mathrm{s}, \mathrm{SCH}_{2}\right) ; \mathrm{m} / z 130\left(\mathrm{M}^{+}-\mathrm{AcOH}\right), 101\left[\mathrm{M}^{+}-(\mathrm{AcOH}+\mathrm{Et})\right], 87,82,67,61,59,55$ and 53.

Compound $\mathbf{4 c}$ was obtained as a mixture with $\mathbf{3 c}$, and the proposed structure was supported by the 
GLC-MS results; the GLC peak for $\mathbf{4 c}$ has a longer retention time than that for $\mathbf{3 c}$ because the AcO group of $\mathbf{4 c}$ is less shielded by non polar groups than the $\mathrm{AcO}$ group of $\mathbf{3 c}$, and the mass spectra for $\mathbf{4 c}$ showed the following peaks: $m / z, 130,117\left(\mathrm{M}^{+}-\mathrm{CH}_{2} \mathrm{OAc}\right), 101,83,82,67,61,59,55$ and 53). The peak $\mathrm{m} / \mathrm{z} 117$ is not observed for $\mathbf{3 c}$, and the appearance of this peak is in good agreement with the proposed anti-Markovnikov structure of $\mathbf{4 c}$. The yield of $\mathbf{4 c}$ was determined using the assumption that $\mathbf{4 c}$ has the same GLC response factor as $\mathbf{3 c}$.

The products $3 \mathbf{d}, \mathbf{4 d}$ and $\mathbf{5 d}$ were also obtained as a mixture, and the mixture indicated the following spectra: $v_{\max }$ (neat) $/ \mathrm{cm}^{-1}$ 2920, 2860, 1728, 1440, 1368, 1242, 1173, 1147, 1112, 1040 and 1025; $\delta_{\mathrm{H}}\left(\mathrm{CDCl}_{3}\right)$ 4.75-4.05 (m, OCH of 4d), 4.05 (s, $\mathrm{CH}_{2} \mathrm{OCOMe}$ of 5d), 2.45-2.75 (m, SCH of 3d and 5d), $2.16(3 \mathrm{H}, \mathrm{s}, \mathrm{SMe}), 2.00(3 \mathrm{H}, \mathrm{s}, \mathrm{OCOMe}), 1.56(\mathrm{~s}, \mathrm{Me})$ and 1.05-1.65 (m, $\mathrm{CH}$ of $\mathbf{5 d}$ and $\left.\mathrm{CH}_{2}\right)$. The GLC-MS for these products exhibited the following separate mass spectra: $m / z$ for $3 \mathbf{d} 202\left(\mathrm{M}^{+}\right), 142$ $\left(\mathrm{M}^{+}-\mathrm{AcOH}\right), 113,95\left[\mathrm{M}^{+}-(\mathrm{AcOH}+\mathrm{SMe})\right], 94,93,79,77,67,55$ and 53; $\mathrm{m} / \mathrm{z}$ for $4 \mathbf{d} 202\left(\mathrm{M}^{+}\right), 142$, 113, 95, 94, 93, 79, 77, 67, 55 and 53; $\mathrm{m} / \mathrm{z}$ for $\mathbf{5 d} 202\left(\mathrm{M}^{+}\right), 163,142,129\left(\mathrm{M}^{+}-\mathrm{CH}_{2} \mathrm{OAc}\right), 95,94,81$, 79, 77, 67, 61, 55 and 53. The comparatively strong peak for $\mathrm{m} / \mathrm{z} 129$ was observed for $\mathbf{5 d}$ but for neither $3 \mathbf{d}$ nor $\mathbf{4 d}$, and the ${ }^{1} \mathrm{H}$ NMR spectra for the mixture of $\mathbf{3 d}, \mathbf{4 d}$ and $\mathbf{5 d}$ showed a peak at $4.05 \mathrm{ppm}$ (singlet, $\mathrm{CH}_{2} \mathrm{OCOMe}$ ). These results lend strong support to the structure of 5d. Considering 2a to be trans-compound, $\mathbf{3 d}$ and $\mathbf{4 d}$ should also have trans-configuration. The low retention time of $\mathbf{3 d}$ compared to $\mathbf{4 d}$ and the high relative-intensity for $\mathrm{m} / \mathrm{z}, 142$ of $\mathbf{3 d}$ relative to $\mathbf{4 d}$ support the proposed structures for $\mathbf{3 d}$ and $\mathbf{4 d}$. The configuration for $\mathbf{5 d}$ is not unambiguous, but it seems reasonable to assume it to be in a trans-form in which the $\mathrm{SMe}$ and $\mathrm{CH}_{2} \mathrm{OAc}$ groups are located at the stable equatorial positions. The yields of $\mathbf{3 d}, \mathbf{4 d}$ and $\mathbf{5 d}$ were also determined with the assumption that these compounds have identical GLC response factors.

Effects of solvents and concentration of AcOH on the reaction of dimethyl disulfide (1) with hex-1-ene (2b) or 2-methylpent-1-ene (2c)

The reaction of dimethyl disulfide (1) with hex-1-ene (2b) or 2-methylpent-1-ene (2c) was performed similarly using various solvents under the conditions indicated in Table 3 . Analysis and characterization of the products were carried out as described above. The results are summarized in Table 3.

Effects of oxidants in the reaction of dimethyl disulfide (1) with hex-1-ene (2b)

The reaction of dimethyl disulfide (1) with hex-1-ene (2b) was also conducted with a variety of oxidants under the conditions shown in Table 4 . The yields of $\mathbf{3 b}$ and $\mathbf{4 b}$ were determined by the same procedure as that described above, and the results are summarized in Table 4.

\section{References and Notes}

1. Smit, W. A.; Zefirov, N. S.; Bodrikov, I. V.; Krimer, M. Z. Acc. Chem. Res. 1979, 12, 282.

2. Trost, B. M.; Ochiai, M.; McDougal, P. G. J. Am. Chem. Soc. 1978, 100, 7103.

3. Bewick, A.; Mellor, J. M.; Owton, W. M. J. Chem. Soc., Perkin Trans. 1 1985, 1039.

4. E. Samii, Z. K. M. A.; Ashmawy, M. I. A.; Mellor, J. M. Tetrahedron Lett. 1986, 27, 52859. 
5. Bewick, A.; Mellor, J. M.; Milano, D.; Owton, W. M. J. Chem. Soc., Perkin Trans. 1 1985, 1045.

6. Bewick, A.; Coe, D. E.; Mellor, J. M.; Owton, W. M. J. Chem. Soc., Perkin Trans. 1 1985, 1033.

7. It has been reported that the disulfide radical cation is highly reactive in solution, regardless of whether it is generated by chemical, photochemical or electrochemical oxidation, and thus the spectral confirmation is difficult in solution; Marti, V.; Fernandez, L.; Garcia, H.; Roth, H. D. J. Chem. Soc., Perkin Trans. 2 1999, 145. We have recently observed that the disulfide radical cation (from MeSSMe) with $\lambda_{\max } 375 \mathrm{~nm}$ is not capable of dissociation into a sulfenium ion, and undergoes an aromatic methylthiolation; the details will be published in the near future.

8. A sulfenium ion seems to be formed in the first instance, but this formation would be impossible because a very unstable sulfenium ion can be generated when it interacts directly with the unshared electron-pair of a compound formed by dissociation from the precursor; In fact, arylsufenium ions are generated by interaction with both the unshared electron-pair of amine and the counterion: Takeuchi, H.; Oya, H.; Yanase, T.; Itou, K.; Adachi, T.; Sugiura, H.; Hayashi, N. J. Chem. Soc., Perkin Trans. 2 1994, 827.

9. Unpublished data; in the near future we will publish the details in which the reaction of $\mathbf{1}$ with alkene using AgOAc proceeds via the thiiranium ion formed from $\left[\mathrm{MeS}-\mathrm{S}^{+}(\mathrm{Me}) \mathrm{Ag}\right]^{-} \mathrm{OAc}$ because of the formation of MeSAg.

10. Mueller, H. Angew. Chem. Int. Ed. Engl. 1969, 8, 482.

11. Lucchini, V.; Modena, G.; Pasquato, L. J. Am. Chem. Soc. 1988, 110, 6900.

12. Lucchini, V.; Modena, G.; Pasquato, L. J. Am. Chem. Soc. 1991, 113, 6600.

13. Huang, X.; Batchelor, R. J.; Einstein, F. W. B.; Bennet, A. J. J. Org. Chem. 1994, 59, 7108.

14. Luccchini, V.; Modena, G.; Pasi, M.; Pasquato, L. J. Org. Chem. 1997, 62, 7018.

15. Ogawa, A.; Tanaka, H.; Yokoyama, H.; Obayashi, R.; Yokoyama, K.; Sonoda, N. J. Org. Chem. 1992, 57, 111.

16. Fristad, W. E.; Peterson, J. R. J. Org. Chem. 1985, 50, 10.

Sample Availability: Available from the authors.

(C) 2000 by MDPI (http://www.mdpi.org). 